\title{
ACCUMULATION OF DISSOLVED DMSP BY MARINE BACTERIA AND ITS DEGRADATION VIA BACTERIVORY
}

\author{
Gordon V. Wolfe \\ College of Oceanic and Atmospheric Sciences \\ Oceanography Administration Bldg. 104 \\ Oregon State University \\ Corvallis, Oregon 97331-5503
}

\section{SUMMARY}

Several bacterial isolates enriched from seawater using complex media were able to accumulate dimethylsulfoniopropionate (DMSP) from media into cells over several hours without degrading it. Uptake only occurred in metabolically active cells, and was repressed in some strains by the presence of additional carbon sources. Accumulation was also more rapid in osmotically-stressed cells, suggesting DMSP is used as an osmotic solute. Uptake could be blocked by inhibitors of active transport systems (2,4-dinitrophenol, azide, arsenate) and of protein synthesis (chloramphenicol). Some structural analogs such as glycine betaine and S-methyl methionine also blocked DMSP uptake, suggesting that the availability of alternate organic osmolytes may influence DMSP uptake. Stresses such as freezing, heating, or osmotic down shock resulted in partial release of DMSP back to the medium. One strain which contained a DMSP-lyase was also able to accumulate DMSP, and DMS was only produced in the absence of alternate carbon sources. Bacteria containing DMSP were prepared as prey for bacterivorous ciliates and flagellates, to examine the fate of the DMSP during grazing. In all cases, predators metabolized the DMSP in bacteria. In some cases, DMS was produced, but it is not clear if this was due to the predators or to associated bacteria in the non-axenic grazer cultures. Bacterivores may influence DMSP cycling by either modulating populations of DMSP-metabolizing bacteria, or by metabolizing DMSP accumulated by bacterial prey.

\section{INTRODUCTION}

Recent investigations have focused attention on the potential role of marine bacteria in the breakdown of phytoplankton-produced dimethylsulfoniopropionate (DMSP) to dimethyl sulfide (DMS) and other products $(8,16,17,24,25,38,39)$. It is likely that bacteria 
are responsible for a substantial fraction of the DMS produced in the ocean. Since methylotrophic bacteria may also consume DMS in surface waters $(18,42)$, the balance between DMS production and removal, which affects DMS concentration, is strongly dependent on bacterial metabolism.

Though not generally considered, other, indirect pathways for DMSP metabolism via bacterial uptake may exist. Much previous work has shown that many bacteria accumulate betaines and similar organic molecules from their environment for use as osmotic solutes $(2,4,5,13,23,30,32,33)$. Frequently, structurally-related compounds function equally well $(1,31)$, including DMSP and other sulfonium compounds (5), and further evidence suggests that DMSP added to growth media counteracts salt-stress in bacteria $(8,29)$. It is therefore possible that many marine bacteria may accumulate DMSP and other solutes from seawater without directly metabolizing them. However, this DMSP may still be metabolized by bacterivorous protists during grazing, as has been shown for herbivorous protists (43), thus representing an additional pathway for degradation of phytoplankton-derived DMSP. Predation may also influence the availability of bacteria capable of scavenging and metabolizing DMSP and DMS, further mediating the abundance of those compounds.

In this study, isolated marine heterotrophic bacterial strains, including one which produced DMS, were tested for their ability to accumulate DMSP from seawater. Bacteria which had accumulated DMSP were used as prey for bacterivorous ciliates and flagellates in order to examine the roles of bactervory in the cycling of this compound, and in the production of DMS.

\section{MATERIALS AND METHODS}

\section{Media for Isolation of Bacteria}

Heterotrophic marine bacteria from phytoplankton cultures and Oregon coastal seawater $\left(9-12^{\circ} \mathrm{C}\right)$ were enriched and isolated by streaking on filtered-seawater agar $(1.5 \%)$ amended with $1 \%$ peptone, glucose, and $0.5 \%$ yeast extract. Cultures were incubated in the dark at room temperature and individual colonies were restreaked to purity. Bacteria were prepared for experiments by picking colonies from the plates, inoculating into $20-200 \mathrm{ml}$ of similar liquid media, and incubating 1-2 days on a shaker at $100 \mathrm{rpm}$.

\section{Selection of DMSP-Metabolizers}

Bacteria were isolated which either lysed or demethylated DMSP by taking advantage of the fact that the lysis reaction produces free acid (protons) and the demethylation reaction does not. Agar plates were prepared as follows: 1 liter of $0.2-\mu \mathrm{m}$ filtered seawater was autoclaved with $15 \mathrm{~g}$ agar (Difco) and $10 \mathrm{mg}$ bromthymol blue and then cooled to $60^{\circ} \mathrm{C}$ in a water bath. Two or $5 \mathrm{~g}(10$ or $25 \mathrm{mM}) \mathrm{DMSP}-\mathrm{Br}$ and $1.6 \mathrm{~g}$ Tris- $\mathrm{OH}(10 \mathrm{mM})$, were dissolved in $40 \mathrm{ml}$ of cold, $0.2 \mu \mathrm{m}$-filtered seawater and $\mathrm{pH}$-adjusted as necessary to 7.6 with $\mathrm{NaOH}$. This solution was sterile-filtered into the $60^{\circ} \mathrm{C}$ agar which was then poured immediately into sterile petri plates. Because DMSP showed thermal degradation to DMS and acrylate above $60^{\circ} \mathrm{C}$, it was not autoclaved. Some plates were made with trace nutrients $(0.01 \%$ glucose, peptone, and yeast extract) added as well to promote general heterotrophic growth or provide trace nutrients.

Bromthymol blue, the $\mathrm{pH}$ indicator dye in these plates, is blue at $\mathrm{pH} 7.5$, colorless at $\mathrm{pH} 6.5$, and yellow at $\mathrm{pH} 6$. Typically, colonies producing acid appear 
green, since the yellow layer around the cells lies on top of a thicker layer of unmodified blue agar. DMSP-lysing colonies were easily detectable by this method, while other colonies (DMSP-demethylators or those growing on other trace carbon sources) appeared white or clear. DMS odor could be detected in all plates, including sterile, unstreaked controls, suggesting that some autolysis of DMSP occurred. This was a small fraction of the total and sterile plates did not shift color over several months or more; however, it did mask biological production of sulfur gases. Plates were streaked with various inocula and incubated at room temperature in the dark.

\section{Demonstration of DMSP Uptake by Bacteria}

Bacteria were either incubated 24-48 hours with 10-100 $\mu \mathrm{M}$ dissolved DMSP during growth on complex substrates (peptone, glucose, yeast extract), or were centrifuged after growth, washed in filtered, autoclaved seawater (FASW), and resuspended in FASW with dissolved DMSP and incubated 4-24 hours at $100 \mathrm{rpm}$ at room temperature. Typical bacterial densities were $10^{7}-10^{8} \mathrm{ml}^{-1}$. After incubation, bacteria were again centrifuged, and a subsample of the supernatent was assayed for remaining dissolved DMSP. The cells were then washed and resuspended in DMSP-free FASW, and a subsample assayed for accumulated DMSP. Samples were placed in 10-ml crimp-top vials, $2 \mathrm{ml} 10 \mathrm{~N} \mathrm{NaOH}$ was added by pipette and the vial was quickly capped with Teflon-lined septa. The bottles were incubated along with DMSP standards at room temperature for 2-24 hours and the DMS produced was sampled in $10-25 \mu 1$ headspace samples taken by gastight syringe. DMS was measured by GC-FPD detection.

Bacterial uptake of DMSP was also measured by filtering cell solutions with $\mathrm{GF} / \mathrm{F}$ or Millipore type HA $0.45 \mu \mathrm{m}$ filters and measuring particulate DMSP retained on the filter. Samples were assayed as for centrifuged samples. Loss of cell DMSP was examined by similar methods after heating to 60,80 , or 100 " $\mathrm{C}$ for 2 hours, freezing, or other treatments. The effect of salinity changes on DMSP uptake was tested by growing cells in FASW, then centrifuging and resuspending them in FASW diluted with distilled water (hypotonic) or amended with $25 \mathrm{~g} \mathrm{liter}^{-1}$ sodium chloride

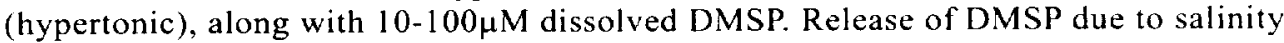
changes was measured by centrifuging DMSP-containing bacteria, then resuspending and incubating them in appropriate media. Salinity was measured by refractometer.

Inhibitor studies. Inhibitors were prepared as $100 \mathrm{mM}$ solutions in deionized water, except for chloramphenicol which was dissolved in ethanol, and then added to bacterial samples (strain 1030) at $1 \mathrm{mM}$ final concentrations (final volume $2 \mathrm{ml}$ ). Ethanol was added to the no-inhibitor control as well to account for any solvent effect. 2,4dinitrophenol was dissolved by adding $\mathrm{NaOH}$ dropwise. Formalin used as a positive control was added directly to cultures to a final concentration of $3.7 \%$. After adding inhibitors, samples were pre-incubated at room temperature in the dark with shaking for 0.5 hour, then DMSP was added to $100 \mu \mathrm{M}$ and the samples incubated overnight at room temperature in the dark with shaking. $0.5-\mathrm{ml}$ subsamples were removed at 0,3 , and 22.5 hours and centrifuged to remove cells. $0.4 \mathrm{ml}$ of the supernatent was assayed for remaining dissolved DMSP by headspace analysis.

\section{Ciliate and Flagellate Cultures}

Protists were enriched and cultured from seawater. Cultures were maintained on bacteria growing on sterilized wheat berries, or on bacterial strains heat-killed for $1 \mathrm{hr}$ at $80^{\circ} \mathrm{C}$. Cultures were grown in 0.25 or $0.5 \mathrm{~L}$ polycarbonate flasks in the dark. Prior to the experiments, the wheat berries were removed to allow the bacterivores to graze down their 
prey as much as possible. The cultures were diluted into appropriate experimental samples with FASW and allowed to incubate overnight at $15^{\circ} \mathrm{C}$ before prey bacteria, DMSP, or other amendments were added.

\section{Bottle Incubations}

Protists and prey were incubated in $500-$ or $250-\mathrm{ml} \mathrm{Nalgene} \mathrm{polycarbonate} \mathrm{flasks,}$ filled completely to minimize headspace. Duplicate bottles of each treatment were prepared. Sampling during the experiments typically introduced headspace volumes less than $10 \%$ of the total bottle volume over several days. Bottles were handled gently to avoid aeration and were incubated in the dark at $15^{\circ} \mathrm{C}$.

Cell Enumeration. Heterotrophic flagellate and bacterial prey cells were enumerated every 12-24 hours during incubations. $0.5-2 \mathrm{ml}$ culture samples were preserved with alkaline Lugol's reagent $\left(10 \mu \mathrm{ml}^{-1}\right)$ followed by sodium tetraborate-buffered formalin $(3.7 \%$ final concentration). The Lugol's was bleached by the addition of 1 drop $\mathrm{ml}^{-1} 3 \%$ sodium thiosulfate (35). Samples were then stained with acridine orange (AO) or 4',6-diamidino-2phenylindole (DAPI) and filtered onto black 0.2 or $0.8 \mu \mathrm{m}$ membrane filters (Poretics, Livermore CA, \#11053,11021) immediately after preservation, and counted by epifluorescence microscopy. Actively swimming ciliates were enumerated directly with a dissecting

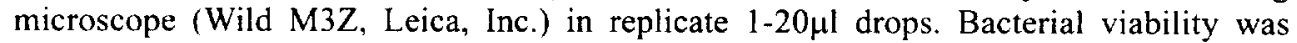
determined during incubations by the Live/Dead® BacLight ${ }^{\mathrm{TM}}$ viability kit (Molecular Probes, Inc., \#L-7007).

\section{Sulfur Analyses}

Sulfur analyses were made by GC using a Shimadzu GC-14 chromatograph equipped with a flame photometric detector. The column packing was Chromosil 330 (Supelco, Bellefonte, PA), operated isothermally at 60 or $90^{\circ} \mathrm{C}$. Helium was the carrier gas. Headspace samples $(10-25 \mu \mathrm{l})$ were collected by gastight syringe and injected onto the column (injector $200^{\circ} \mathrm{C}$ ) and were sampled in triplicate. Stock DMSP solutions were treated as other headspace samples for standards. For DMS analyses, 1- or 2-ml samples were sparged with $\mathrm{He}$, cryotrapped in liquid nitrogen, and subsequently introduced onto the GC column with heating. For DMSP, a separate $1-2 \mathrm{ml}$ sample was filtered through a $\mathrm{GF} / \mathrm{F}$ filter under gentle filtration, and the filter was placed in $10 \mathrm{~N} \mathrm{NaOH}$ for at least 6 hours. A subsample of the $\mathrm{NaOH}$ was then sparged/cryotrapped for DMS produced from the alkaline hydrolysis of particulate DMSP. For dissolved DMSP, the filtrate was first sparged to remove DMS, and $1 \mathrm{ml}$ was then sparged with an equal volume of $10 \mathrm{~N} \mathrm{NaOH}$ and cryotrapped as DMS. Minimum detection limit was approximately $100 \mathrm{pg} \mathrm{S}$. For additional analytical details see (43).

Chemicals. DMSP. $\mathrm{HCl}$ was obtained from Research Plus (Bayonne, $\mathrm{NJ}$ ) and was prepared in concentrated solutions in water. Stocks were kept frozen until use, and after dilution into seawater the $\mathrm{pH}$ was checked to make sure samples were not acidified. Stocks for $\mathrm{GC}$ standards were further acidified with $\mathrm{HCl}$ to prevent bacterial growth and stored at room temperature. DMSP- $\mathrm{HBr}(>90 \%$ purity) used for isolation media was synthesized from DMS and 3-bromo-propionic acid (Aldrich) according to the method of Kondo (20) and was verified by melting point $\left(112-113^{\circ} \mathrm{C}\right)$ and NMR spectroscopy. Sources for inhibitors were: glycine betaine $\mathrm{HCl}$, DL-S-methyl methionine, sodium azide, sodium arsenate, L-proline, and chloramphenicol, Sigma Chemicals; N,N-dimethyl glycine $\mathrm{HCl}$, Aldrich Chemicals; 2,4-dinitrophenol, Kodak Chemicals. 


\section{RESULTS}

\section{Marine Bacteria Accumulated Dissolved DMSP}

Five strains of marine heterotrophic bacteria were isolated on rich media. Four were gram-negative, and one (strain 0030) was gram-positive. All strains but 4030 readily took

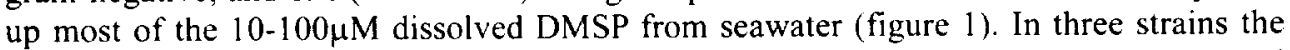
DMSP appeared to be stored inside cells rather than metabolized, and one accumulated DMSP with subsequent lysis to DMS (strain 0010). Some cells appeared to increase DMSP uptake at higher salinity (figure 1, strains 0030, 1010), suggesting an osmotic use, but others showed no such response (figure 1, strain 1030).

One accumulator (strain 1030) and the lyser (strain 0010) were selected for more detailed studies. Uptake times typically ranged from minutes (figure 2) to hours (figure 4a). However, bacterial numbers or biomass were not constant between experiments, so rate comparisons are not meaningful. Uptake occurred both during growth on complex substrates, or following growth when washed cells were resuspended in seawater amended with 10-100 $\mu$ M DMSP. Occasionally, bacteria appeared to take up DMSP more rapidly in the presence of other $C$ compounds, but more typically strains accumulated DMSP more quickly in their absence. The additional carbon sources may have provided alternative osmolytes which competitively block uptake of DMSP (see below); this inhibition was overcome in many strains when bacteria were incubated in double-salinity seawater (data not shown). Uptake of $10-100 \mu \mathrm{M}$ dissolved DMSP resulted in internal cell concentrations of approximately 10-100 $\mathrm{mM}$, based on whole-cell volumes.

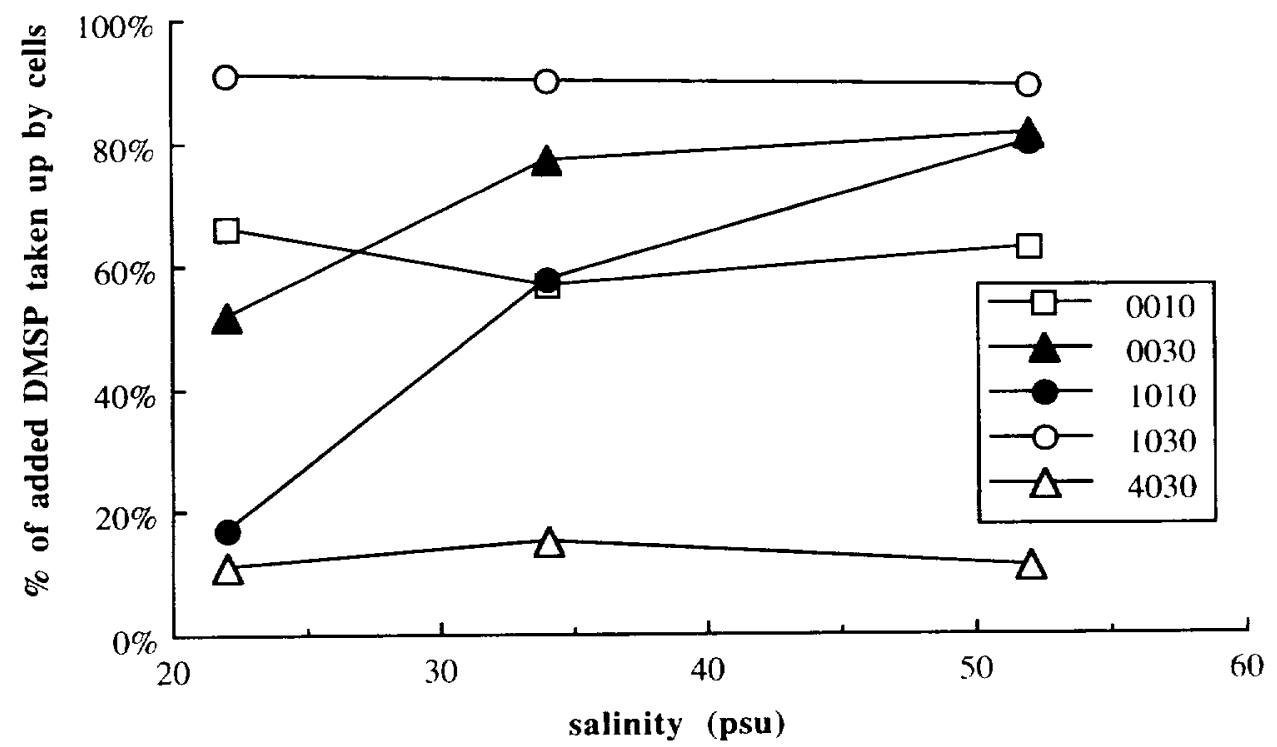

Figure 1. Example of cell uptake of dissolved DMSP. Dissolved DMSP was added to filtered, autoclaved seawater and assayed at time zero; bacterial culture (strain 0010) was added at 0.5 min (arrow). 


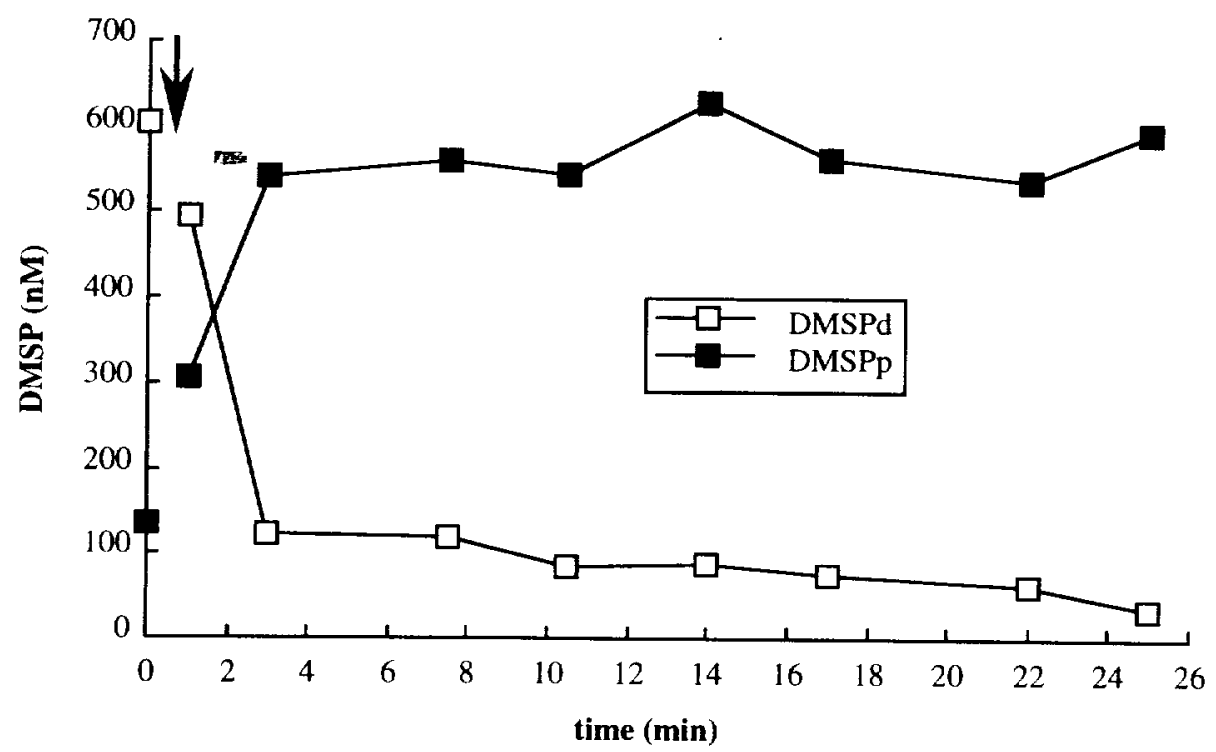

Figure 2. Effect of salinity on accumulation of dissolved DMSP from seawater by marine bacteria. Bacteria were incubated with $10 \mu \mathrm{M}$ DMSP for $16 \mathrm{hr}$ in either filtered, autoclaved seawater, seawater amended with $\mathrm{NaCl}$, or seawater diluted with deionized water.

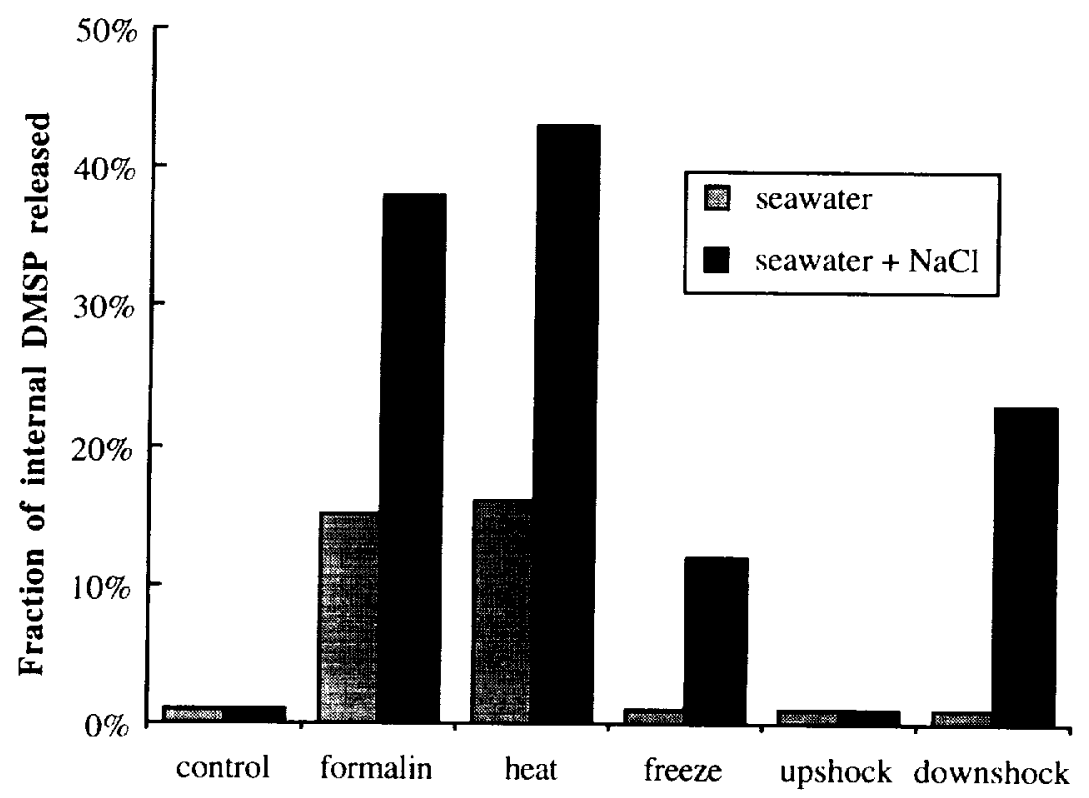

\section{Treatment}

Figure 3. Release of DMSP from bacteria following shock treatments, including poisons, heating, freezing, and osmotic downshock. More DMSP was released when cells were already osmotically stressed. Data are for strain 1030 


\section{DMSP Uptake Could Be Blocked by Uptake Inhibitors and Other Osmolytes}

DMSP appeared to be taken up actively by cells. Formalin-treated bacteria did not take up DMSP from seawater and DMSP did not attach onto ion exchange resin particles such as Sephadex, so adsorption was probably not a factor. Cells heated 1-2 hrs at 80 or $100^{\circ} \mathrm{C}$ showed no uptake, but cells heated to only $60^{\circ} \mathrm{C}$ remained active (data not shown) and were capable of growth when plated onto rich media. Pre-incubating bacteria (strain 1030) with inhibitors of transport systems or protein synthesis generally prevented uptake (table 1). Some substrate analogs effectively blocked DMSP uptake (glycine betaine, S-methyl methionine) while other organic osmolytes had reduced (dimethyl glycine) or no (L-proline) effect. Staining cells with the BacLight ${ }^{\mathrm{TM}}$ viability kit showed that the glycine betaine was not lethal to cells, so uptake was presumably blocked by competition.

DMSP could be stored inside cells for days without degradation, either in concentrated cell solutions or after cells were resuspended in seawater. In many instances, though, after resuspension and dilution of DMSP-containing cells, DMSP returned to the "dissolved" fraction over several days (see grazing results below). This may have been due to slight osmotic differences between the concentrated bacterial stock media and the seawater used for the grazing experiments, or possibly due to handling shock. Other stresses such freezing or heating cells resulted in release of DMSP to the media (figure 3). Poisons or osmotic down shock also resulted in release, while osmotic upshock did not. Greater release occurred in cells already stressed osmotically in seawater amended with $\mathrm{NaCl}$ (figure 3 ).

\section{A DMSP-Lysing Strain Also Accumulated DMSP Depending on External Conditions}

Strain 0010, able to cleave DMSP to form DMS, was able to accumulate and retain DMSP from solution as well. Uptake was greatest under conditions of osmotic stress (figure 4a) and was partially repressed when other C substrates (peptone, yeast extract, glucose) were present. Production of DMS following uptake was greatest at higher salinities as well (figure 4b), but DMS production was completely suppressed when other carbon substrates were present. These observations suggest that some DMSP-lysing bacteria may also be able to use DMSP as an osmolyte, and that cleavage to DMS and acrylate may depend on the presence of other carbon sources.

\section{Bacterivores Were Able to Utilize DMSP Accumulated in Their Prey}

When live, DMSP-containing bacteria were fed to a bacterivorous scuticociliate (Uronema sp.), bacterial cell numbers began to decline immediately due to grazing (figure 5b). After a 24-hr lag, ciliate numbers increased (figure 5a) and bacterial DMSP decreased (figure $6 \mathrm{~b}$ ). These results suggest that the grazers metabolized prey DMSP within $24 \mathrm{hr}$ of ingestion. Ungrazed bacteria containing DMSP showed little decrease in cell number (figure $5 \mathrm{~b}$ ), but they did release DMSP to seawater (figure 6a). However, in ungrazed bacteria, total DMSP was conserved and no DMS was produced (figure 6a). A small amount of DMS was produced in the grazed cultures, probably from bacterial associates of the scuticociliates, since scuticociliate cultures streaked onto DMSP agar plates gave positive results for lysers. No axenic ciliate 


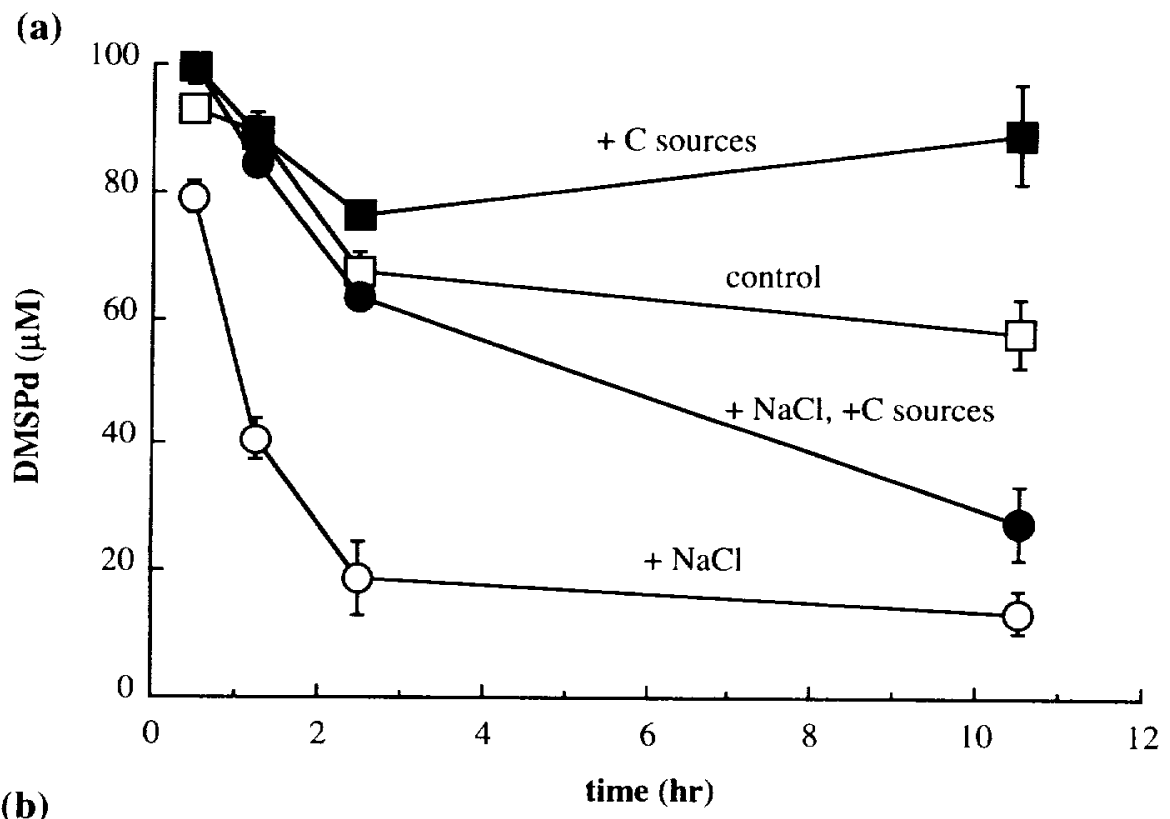

(b)

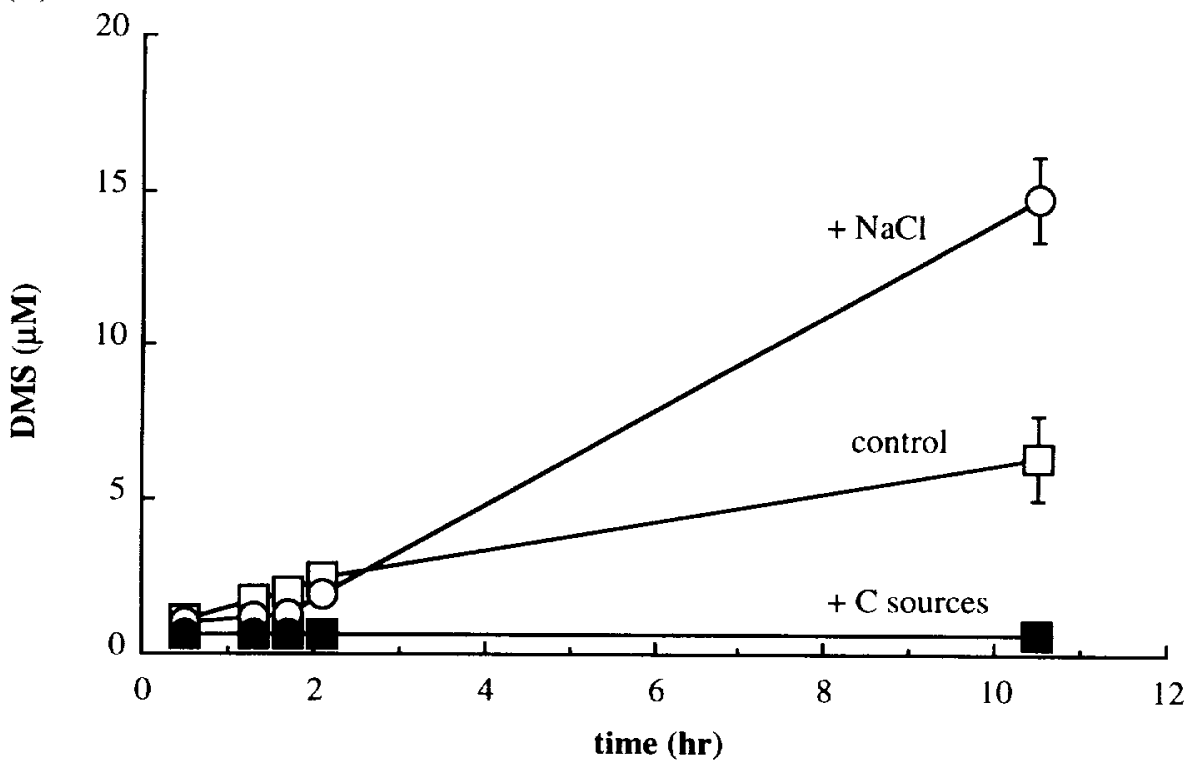

Figure 4. Accumulation of DMSP by DMSP-cleaving bacterium (strain 0010), and dependence of DMS production on external conditions. (a): uptake of dissolved DMSP by strain 0010 was hastened when grown in 56 psu seawater compared to uptake in 32 psu seawater. Addition of other C sources (peptone, glucose, yeast extract) decreased uptake partially in all cases, but at higher salinities uptake still occurred. (b) production of DMS by 0010 culture was completely suppressed by addition of other $C$ sources and production was increased at higher salinities. Note different scales for two graphs. 


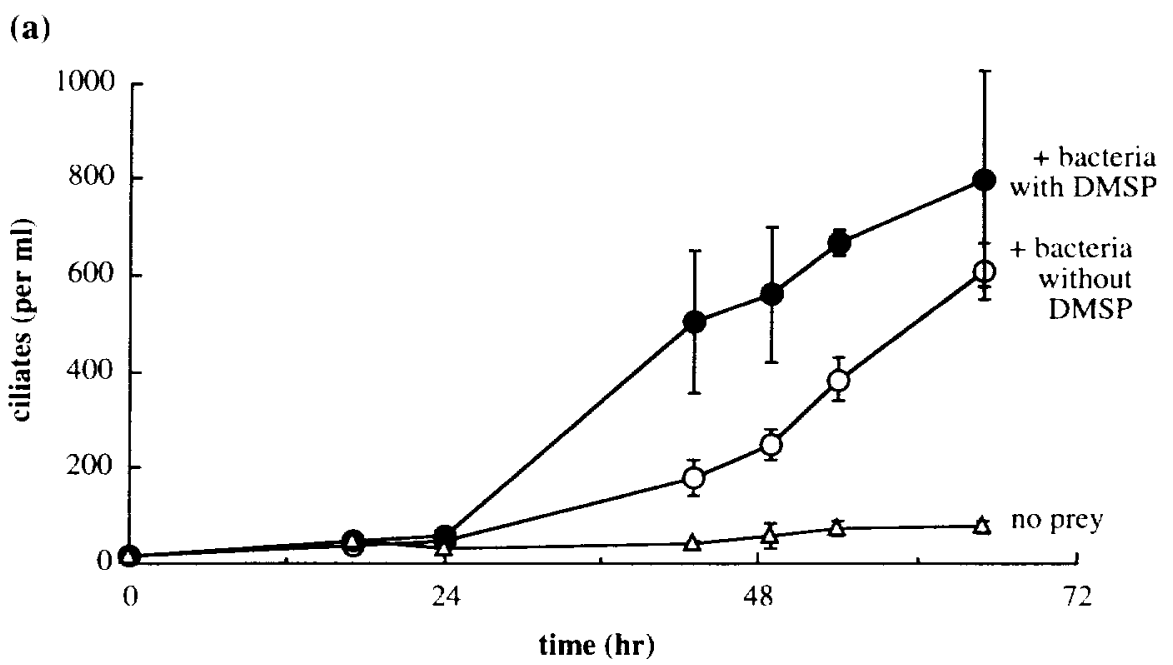

(b)

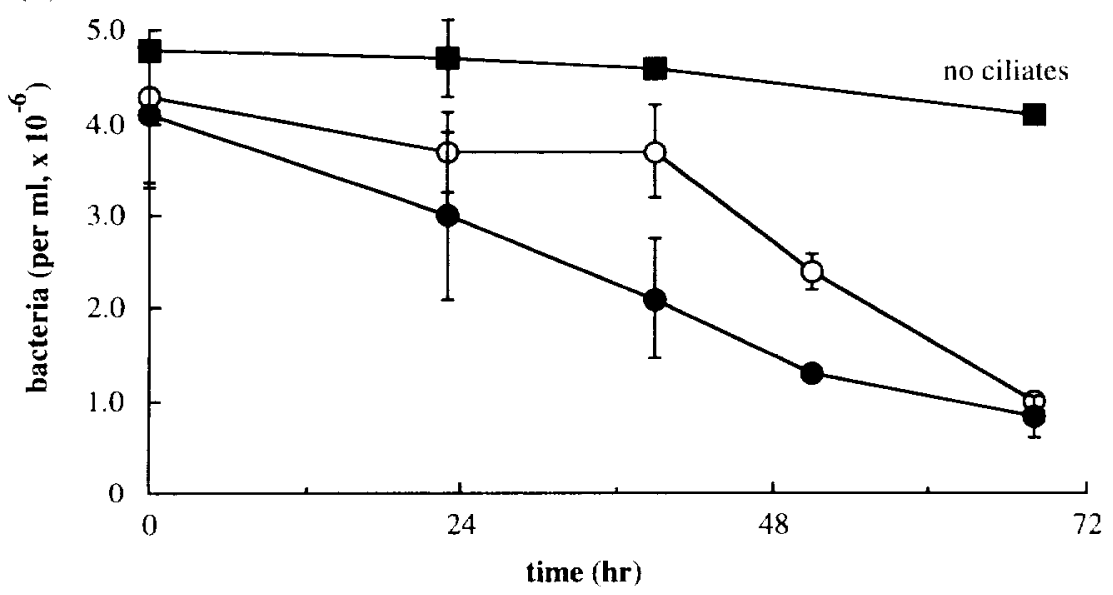

Figure 5. Grazing by scuticociliate on bacterial strain 1030 pre-incubated with DMSP ( $\odot$ ) or without DMSP (O). (a): ciliate numbers vs. time; $(\Delta)$ are ciliates without added prcy. (b): bacterial numbers vs. time; $(\square)$ is strain 1030 with DMSP ("1030+") but no ciliates.

cultures were available to test whether the DMSP lysis might in fact be due to ciliates themselves.

Similar results were also obtained in grazing experiments with a flagellate (Cafeteria sp., data not shown). Once again, although ungrazed bacteria released DMSP, total DMSP was conserved, as were bacterial numbers, while in the grazed samples both decreased. In this case, though, a fraction of DMSP was converted to DMS in both grazed and ungrazed samples.

With both predators, bacteria which contained up to $100 \mathrm{mM}$ internal DMSP were not grazed any faster than those without, nor did grazer appearance or the increase in grazer number vary with prey DMSP, suggesting that even high internal DMSP pools in bacterial prey made little nutritional difference to predators. 


\section{DISCUSSION}

\section{Accumulation of Dissolved DMSP by Marine Bacteria}

Bacteria are recognized to play a role in the cycling of phytoplankton-derived DMSP in marine systems. Most work on bacterial pathways for DMSP has focused on those which metabolize it as a carbon source, either by lysis to DMS and acrylate or by demethylation to 3 -methiol propionate $(8,16,17,24,25,38-40)$. Bacteria which could contribute to these pathways may be significant $(10 \%)$ fraction of the total bacterial population in some marine surface waters (39), and several strains have been isolated.

However, bacteria may also take up dissolved DMSP without metabolizing it, and this process has not been emphasized in studies of DMSP cycling in marine surface waters, despite the fact that much work has documented bacterial uptake of other osmotic solutes such as choline and glycine betaine $(1,4,5,22,30-32)$. De novo synthesis of betaine is rare
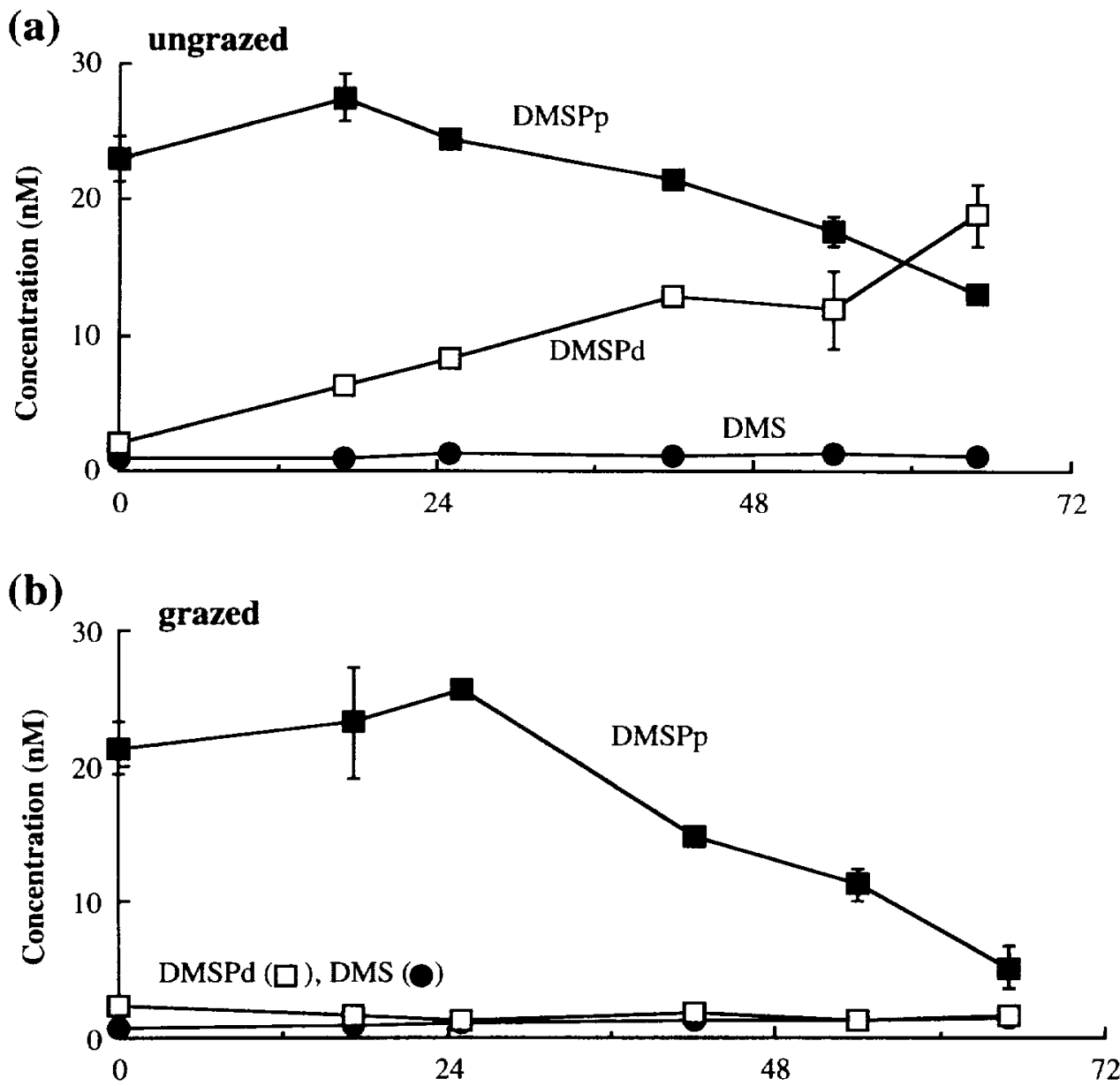

Figure 6. Sulfur pools for scuticociliate grazing on bacterial strain 1030 pre-incubated with DMSP. Symbols: ( ) DMSPp; ( $\square$ ) DMSPd; ( ) : DMS. (a) Bacteria without grazers. DMSPp in the bacteria leaked out over 3 days to the dissolved pool but no DMS was formed, and there was no net loss of DMSP. (b) Bacteria with grazers. No dissolved DMSP appears but bacterial DMSP disappears as bacteria are grazed. 
in eubacteria and seems limited to moderately or extremely halophilic eubacteria, especially phototrophs (41). More slightly halophilic eubacteria either accumulate betaine from their environment or produce it from externally-acquired choline $(2,12)$. Many eubacteria, particularly those in the Enterobacteriacae, accumulate these solutes but do not utilize them as carbon sources, while others such as Rhizobium can both accumulate and metabolize these solutes, depending on both salinity stress and nutrient needs (36). The non-metabolizers may also actively export these solutes to maintain osmotic balance $(21,37)$. In addition to the quaternary amines, enteric bacteria have been shown to accumulate DMSP and related sulfonium compounds $(5,31)$, and this study suggests that many marine bacteria may do so as well. Only one previous study (8) demonstrated that a marine bacterium could accumulate DMSP at high salinities, although that work focused on the ability of that strain to degrade DMSP at normal seawater salinities.

The majority of bacterial strains in this study appeared to take up $\mu$ M DMSP from seawater over a range of salinities (figures $1 \mathrm{~b}, 4 \mathrm{a}$ ). Uptake rates varied among strains, and were influenced by environmental conditions such as the availability of alternate carbon substrates. In all cases, though, uptake appeared to be the result of active metabolism. Heator formalin-killed cells did not take up DMSP, and inhibitors of transport systems such as 2,4-dinitrophenol, azide, or arsenate prevented uptake (table 1).

DMSP was accumulated to $\mathrm{mM}$ internal concentrations, based on whole-cell volume calculations. However, it is possible that DMSP is stored in the cell periplasm or other sub-volume. Stresses such as freezing, heating, osmotic down shock, or poisoning all resulted in partial release of DMSP to the medium (figure 3), and frequently, dilution of concentrated cultures into seawater resulted in slow leakage of DMSP out of cells (figure $6 a)$. This may have been due to handling stress during dilution. However, strain 1030, which was used for most of the grazing experiments, was shown by fatty acid MIDI analysis to be an enteric, corresponding most closely to Enterobacter agglomerans (R. Herwig, personal communication). This strain did not appear to metabolize DMSP. Since export pumps for osmotic solutes such as glycine betaine are well known for enterics which do not further catabolize it as a carbon source $(21,37)$, the release of DMSP by this strain may also have been an osmoregulatory effect.

Most of the strains appeared to retain DMSP without metabolism, but one DMSPlysing strain (0010) also accumulated DMSP from the medium (figure 4a). Although the presence of other carbon sources slowed DMSP uptake, it did not prevent it. However, the production of DMS by this strain was completely blocked when other carbon sources were

Table 1. Effect of inhibitors ( $1 \mathrm{mM}$ ) on accumulation of 100:M DMSP by strain 1030

\begin{tabular}{lcc}
\hline \multicolumn{1}{c}{ Metabolic type } & Compound & $\%$ lnhibition \\
\hline Controls & none (- control) & 0 \\
& formalin (+ control) & 100 \\
Uptake system poisons & dinitrophenol & 100 \\
& sodium azide & 100 \\
Protein synthesis inhibitor & sodium arsenate & 81 \\
Substrate analogs & chloramphenicol & 100 \\
& Glycine betaine & 99 \\
Other osmolytes & S-methyl methionine & 86 \\
& dimethyl glycine & 67 \\
& L-proline & n.s. ${ }^{2}$
\end{tabular}

\footnotetext{
${ }^{1}$ percent reduction in regression slope of DMSP uptake over time relative to no-inhibitor control

${ }^{2}$ not significantly different than no-inhibitor control
} 
available, suggesting a possible dual-role of DMSP as both an osmotic solute and a carbon source. This is similar to the use of glycine betaine by Rhizobium (36) which can exploit it for either purpose, depending on environmental conditions.

These observations suggest that the role of marine bacteria in the cycling of phytoplankton-derived DMSP may be greater than previously suspected, since it is not limited only to those which can utilize DMSP as a carbon source. Furthermore, although lysis of DMSP is usually quite specific to that compound $(7,31)$, uptake of DMSP for use as an osmotic solute may be less tightly controlled, and may be influenced by the relative availability of DMSP and other organic solutes which can compete for uptake system proteins. Such competition has been demonstrated for glycine betaine and DMSP $(1,5,8)$, and other solutes present in seawater may also influence DMSP uptake. In this study, both glycine betaine and S-methyl methionine blocked DMSP uptake in strain 1030, while other solutes (L-proline, dimethyl glycine) did not. Glycine betaine has recently been used to inhibit bacterial DMSP lysis in seawater (19), and it is possible that this effect is due to competition for bacterial uptake systems rather than for the DMSP-lyase itself. The presence of yeast extract, known to be a rich source of glycine betaine (12), along with other carbon sources appeared to decrease uptake of DMSP by most strains, although this effect could be reduced when additional salt stress was imposed (data not shown).

\section{Fate of Bacterial DMSP during Grazing by Microzooplankton}

Although bacterial metabolism is probably a major sink for phytoplankton-derived DMSP, bacteria which accumulate DMSP without metabolizing it may also lead to its removal indirectly, during grazing by bacterivores. Similar to results with herbivorous flagellates (43), the passage of DMSP across trophic levels results in its degradation by bacterial grazers, including both ciliates and flagellates (figure 6). It is not yet clear whether the protists themselves are able to produce DMS from prey DMSP. Although DMS was produced in some grazing experiments, it may have been the result of other bacteria associated with the grazer cultures utilizing dissolved DMSP released from the test prey, since the grazer cultures tested positive for DMSP-lysing bacterial strains.

Because DMSP and other osmotic solutes accumulate to high internal concentrations inside prey, it is possible that they may influence the nutritional quality of prey to predators. DMSP and betaine have been shown to function as methyl donors in plants (3), flagellates (15), fish and birds (28), and mammalian cells $(9,27,28)$. Whether bacterivores can utilize DMSP as a methyl donor is not clear, but at least some appear to metabolize it without significant production of DMS, consistent with this function. It is therefore possible that prey containing large concentrations of these compounds might be nutritionally advantageous for predators. However, neither ciliates nor flagellates grazing on bacteria which contained up to $100 \mathrm{mM}$ internal DMSP showed any increase in feeding or growth rates compared to those grazing on bacteria containing no DMSP (data not shown). It is unlikely therefore that DMSP confers any nutritional advantage to predators, especially in natural waters, where prey are less abundant and more heterogeneous. It is possible that uptake of organic solutes such as DMSP effects other changes in bacterial physiology (e.g. size, motility) which in turn influences their desirability as prey for bacterivores.

\section{Implications for DMSP Cycling in Marine Surface Waters}

There are two separate mechanisms by which DMSP accumulates in marine microorganisms: (a) by biosynthesis, which to date has been shown only for phytoplankton and for one heterotrophic dinoflagellate (14); and (b) by uptake of dissolved DMSP for use as 
osmotic solutes, without degradation. A third pool of accumulated DMSP resides in mesoand macroorganisms from DMSP ingested in the diet (see for example Iida (11), Levasseur (26), and Dacey (6) and references therein). Although the latter has received notice because it can lead to odor problems in commercial fish and shellfish, it is likely insignificant compared to the pool of DMSP in microorganisms. Similar accumulation in microzooplanktonic herbivores and bacterivores may also occur, although cultures examined to date appear to metabolize the DMSP rapidly (43).

Despite the evidence shown here that the bacterial uptake mechanism may occur, it is not at all obvious that it plays an important role in DMSP cycling in natural systems. In particular, there are three questions which need to be addressed: (I) Could DMSP accumulated in bacteria be a significant fraction of total DMSP? (ii) Does accumulation occur in natural waters where bacterial concentrations and DMSP concentrations are low? (iii) Could grazing of DMSP-containing bacteria be a major loss pathway for phytoplankton-derived DMSP?

It is not clear whether a significant fraction of the "dissolved" or "particulate" DMSP measured in natural seawater might actually be DMSP stored in bacteria. Although the bacteria in this study were retained on GF/F filters, they were also extremely large cells, compared to typical marine bacteria. It is quite likely that some marine bacteria may pass through $\mathrm{GF} / \mathrm{F}$ filters (nominal size retention $0.8 \mu \mathrm{m}$ ). However, these probably do not contribute significantly to the "dissolved" DMSP pool. For example, if $10 \%$ of the typical $10^{6}$ bacteria $\mathrm{ml}^{-1}$ contained $100 \mathrm{mM}$ DMSP, and all these were spheres of diameter $0.8 \mu \mathrm{m}$ and could pass through a GF/F filter, they would contribute about 2.7 nM DMSP to the "dissolved" pool. Since "dissolved" DMSP concentrations are frequently $10 \mathrm{nM}$ or greater, this seems a small contribution, especially given the generous assumptions. Furthermore, filtration with $0.2 \mu \mathrm{m}$-pore filters and tests with dialysis membranes have shown that there really is a pool of dissolved DMSP, at least in some waters (R.P. Kiene, personal communication). Clearly, larger bacteria, as well as those attached to surfaces, will contribute to the particulate DMSP pool. But because particulate DMSP concentrations are usually greater than for dissolved DMSP, similar calculations show the bacterial contribution is again likely to be minor. However, it is still possible that in certain environments, bacterial DMSP may contribute significantly to either DMSP pool.

Does bacterial accumulation of DMSP occur at the low dissolved DMSP concentrations (typically well below $0.1 \mu \mathrm{M}$ ) which occur in most marine environments? Accumulating DMSP against enormous concentration gradients from very dilute solutions is metabolically expensive. Furthermore, other solutes may be more abundant than DMSP in seawater and may compete with DMSP for cell receptor sites. Glycine betaine blocked accumulation of DMSP by some of the bacteria in this study (table 1), and betaine appears to block metabolism of dissolved DMSP by natural microbial assemblages (19), possibly by preventing its uptake into the cells. Betaine and choline probably occur in marine waters and sediments in concentrations similar to dissolved DMSP (34). Therefore, it is possible that accumulation of DMSP by marine bacteria may not occur to the degree indicated by these bottle experiments where both DMSP and bacterial concentrations were artificially elevated.

Whether the bactivory pathway is an important sink for phytoplankton-derived DMSP in natural environments is difficult to evaluate. The great majority of marine bacteria do not appear to be metabolically active, based on selective staining techniques which measure respiratory activity (44) or DNA (45). Because DMSP uptake requires metabolically active cells, it is therefore likely that only a small fraction of marine bacteria may accumulate DMSP, even though many genera may be able to take up this compound. This seems to imply that if bacterivores utilize random selection of their prey, their chance of ingesting and degrading DMSP inside bacteria would be low. However, there is good evidence that some bacterivores do preferentially graze metabolically-active bacteria (10), raising the possibility that DMSP-containing bacteria might be preferentially selected, especially if DMSP confers any increase in size or motility to cells. It is also not yet clear whether many bacterivorous 
ciliates and flagellates can metabolize DMSP in their prey, or whether they may produce DMS from this DMSP.

Clearly, the experiments reported here, using high DMSP concentrations, high bacterial and bacterivore populations, and long incubation periods, present only the possibility that bacterial accumulation of DMSP and its subsequent degradation by bacterivores may be important in natural waters. Further work is needed to assess the importance of this mechanism on the removal of phytoplankton-produced DMSP in natural waters.

\section{ACKNOWLEDGMENTS}

This work was supported by NASA grant \# NAGW-3737. Lynne Fessenden isolated protist cultures. Russell Herwig performed the fatty acid MIDI analysis. I thank Barry and Evelyn Sherr for discussions, and Ron Kiene for helpful comments and for sharing an unpublished manuscript.

\section{REFERENCES}

1. Abdel-Ghany, Y. S., M. A. Ihnat, D. D. Miller, C. M. Kunin and H. H. Tong. 1993. Structure-activity relationship of glycine betaine analogs on osmotolerance of enteric bacteria. J. Med. Chem. 36: 784-489.

2. Boch, J., B. Kempf and E. Bremer. 1994. Osmoregulation in Bacillus subtilis: synthesis of the osmoprotectant glycine betaine from exogenously provided choline. J. Bact. 176: 5364-5371.

3. Byerrum, R. U., C. S. Sato and C. D. Ball. 1956. Utilization of betaine as a methyl group donor in tobacco. Plant Physiol. 31: 374-377.

4. Chambers. S. and C. M. Kunin. 1985. The osmoprotective properties of urine for bacteria: the protective effect of betaine and human urine against low $\mathrm{pH}$ and high concentrations of electrolytes, sugars, and urea. J. Infect. Dis. 152: 1308-1316.

5. Chambers, S. T., C. M. Kunin, D. Miller and A. Hamada. 1987. Dimethylthetin can substitute for glycine betaine as an osmoprotectant molecule for Escherichia coli. J. Bact. 169: 4845-4847.

6. Dacey. J. W. H., G. M. King and P. S. Lobel. 1994. Herbivory by reef fishes and the production of dimethylsulfide and acrylic acid. Mar. Ecol. Prog. Ser. 112: 67-74.

7. de Souza, M. P. and D. C. Yoch. 1995. Purification and characterization of dimethylsulfoniopropionate lyase from an Alcaligenes-like dimethyl sulfide producing marine isolate. Appl. Environ. Microbiol. 61: 21-26.

8. Diaz, M. R., P. T. Visscher and B. F. Taylor. 1992. Metabolism of dimethylsulfoniopropionate and glycine betaine by a marine bacterium. FEMS Micro. Lett. 96: 61-66.

9. du Vigneaud, V., A. W. Moyer and J. P. Chandler. 1948. Dimethylthetin as a biological methyl donor. J. Biol. Chem. 174: 477-480.

10. González, J. M., E. B. Sherr and B. F. Sherr. 1993. Differential feeding by marine flagellates on growing versus starving, and on motile versus nonmotile, bacterial prey. Mar. Ecol. Prog. Ser. 102: 257-267.

11. Iida, H., K. Nakamura and T. Tokunaga. 1985. Dimethyl sulfide and dimethyl- $\beta$-propiothetin in shellfish. Bull. Jap. Soc. Sci. Fish. 51: 1145-1150.

12. Imhoff, J. F. 1986. Osmoregulation and compatible solutes in eubacteria. FEMS Micro. Rev. 39: 57-66.

13. Imhoff, J. F. and F. Rodriguez-Valera. 1984. Betaine is the main compatible solute of halophilic eubacteria. J. Bact. $160: 478-479$.

14. Ishida, Y. and H. Kadota. 1967. Isolation and identification of dimethyl- $\beta$-propiothetin from Gyrodinium cohnii. Agr. Biol. Chem. 31: 765-767.

15. Ishida, Y. and H. Kadota. 1968. Participation of dimethyl- $\beta$-propiothetin in transmethylation reaction in Gyrodinium cohnii. Bull. Jap. Soc. Sci. Fish. 34: 699-705.

16. Kiene, R. P. 1990. Dimethyl sulfide production from dimethylsulfoniopropionate in coastal seawater and bacterial cultures. Appl. Environ. Microbiol. 56: 3292-3297.

17. Kiene, R. P. 1992. Dynamics of dimethyl sulfide and dimethylsulfoniopropionate in oceanic water samples. Mar. Chem. 37: 29-52.

18. Kiene, R. P. and T. S. Bates. 1990. Biological removal of dimethyl sulfide from seawater. Nature 345 : 702-705. 
19. Kiene. R. P. and G. Gerard. 1995. Evaluation of glycine betaine as an inhibitor of dissolved dimethylsulfoniopropionate degradation in marine waters. Mar. Ecol. Prog. Scr. 128: 121-131.

20. Kondo, H. and M. Ishimoto. 1987. Thetin. Meth. Enzymol. 143: 227.

21. Koo. S.-P.. C. F. Higgins and I. R. Booth. 1991. Regulation of compatible solute accumulation in Salmonella typhimurium: evidence for a glycine betaine efflux system. J. Gen. Micro. 137: 2617-2625.

22. Lamark, T., O. B. Styrvold and A. R. Strom. 1992. Efflux of choline and glycine betaine from osmoregulating cells of Escherichia coli. FEMS Micro. Lett. 96: 149-154.

23. Le Rudulier, D. and B. Perroud. 1983. Glycine betaine, an osmotic effector in Klebsiella pneumoniae and other members of the Enterobacteriaceae. Appl. Environ. Microbiol. 46: 152-159.

24. Ledyard, K. M. and J. W. H. Dacey. 1994. Dimethylsulfide production from dimethylsulfoniopropionate by a marine bacterium. Mar. Ecol. Prog. Ser. 110: 95-103.

25. Ledyard, K. M., E. F. DeLong and J. W. H. Dacey. 1993. Characterization of a DMSP-degrading bacterial isolate from the Sargasso Sea. Arch. Microbiol. 160: 312-318.

26. Levasseur, M., M. D. Keller, E. Bonneau. D. D’Amours and W. K. Bellows. 1994. Oceanographic basis of a DMS-related Allantic cod (Gadus morhua) fishery problem: blackberry feed. Can. J. Fish. Aquat. Sci. 5 I: $881-889$

27. Maw. G. A. and V. du Vigneaud. 1948. Dimethyl- $\beta$-propiothetin, a new methyl donor. J. Biol. Chem. 174: $381-382$.

28. Nakajima, K. 1993. Dimethylthetin- and betaine-homocysteine methyltransferase activities from livers of fish, chicken, and mammals. Nippon Suisan Gakkaishi 59: 1389-1393.

29. Paquet, L., B. Rathinasabapathi, H. Saini, L. Zamir, D. A. Gage, Z.-H. Huang and A. D. Hanson. 1994. Accumulation of the compatible solute 3-dimethylsulfoniopropionate in sugarcane and its relatives, but not other gramineous crops. Aust. J. Plant Physiol. 21: 37-48.

30. Patchett. R. A.. A. F. Kelly and R. G. Kroll. 1994. Transport of glycine-betaine by Listeria monocytogene's Arch. Microbiol. /62: 205-210.

31. Peddie. B. A., M. Lever. C. M. Hayman. K. Randall and S. T. Chambers. 1994. Relationship between osmoprotection and the structure and intracellular accumulation of betaines by Escherichia coli. FEMS Micro. LeIt. 120: 125-132.

32. Perroud. B. and D. Le Rudulier. 1985. Glycine betaine transport in Escherichia coll: osmotic modulation. J. Bact. 161: 393-401.

33. Pocard, I.-A.. T. Bernard, L. T. Smith and D. Le Rudulier. 1989. Characterization of three choline transport activities in Rhizohium meliloti: modulation by choline and osmotic stress. J. Bact. 171: 531-537.

34. Roulier. M. A.. B. Palenik and F. M. M. Morel. 1990. A method for the measurement of choline and hydrogen peroxide in seawater. Mar. Chem. 30:409-421.

35. Sherr, E. B. and B. F. Sherr. 1993. Preservation and storage of samples for enumeration of heterotrophic protists. In P. F. Kemp, B. F. Sherr, E. B. Sherr and J. J. Cole (ed.), Handbook of Methods in Aquatic Microbial Ecology. Pp. 207-212. Lewis Publishers, Boca Raton.

36. Smith, L. T., J.-A. Pocard, T. Bernard and D. Le Rudulier. 1988. Osmotic control of glycine betaine biosynthesis and degradation in Rhizobium meliloti. J. Bact. 170:3142-3149.

37. Snipes, W., A. Keith and P. Wanda. 1974. Active transport of choline by a marine pseudomonad. J. Bact. 120: $197-202$

38. Taylor, B. F. and D. C. Gilchrist. 1991. New routes for aerobic biodegradation of dimethylsulfoniopropionate. Appl. Environ. Microbiol. 57:3581-3584

39. Visscher, P. T., M. R. Diaz and B. F. Taylor. 1993. Enumeration of bacteria which cleave or demethylate dimethylsulfoniopropionate in the Caribbean Sea. Mar. Ecol. Prog. Ser. 89: 293-296.

40. Visscher, P. T. and B. F. Taylor. 1994. Demethylation of dimethylsulfoniopropionate to 3-mercaptopropionate by an aerobic marine bacterium. Appl. Environ. Microbiol. 60: 4617-4619.

41. Welsh, D. T. and R. A. Herbert. 1993. Identification of organic solutes accumulated by purple and green sulphur bacteria during osmotic stress using natural abundance ${ }^{13} \mathrm{C}$ nuclear magnetic resonance spectroscopy. FEMS Micro. Ecol. 13: 145-150.

42. Wolfe, G. V. and R. P. Kiene. 1993. Radioisotope and chemical inhibitor measurements of dimethyl sulfide consumption rates and kinetics in estuarine waters. Mar. Ecol. Prog. Ser. 99: 261-269.

43. Wolfe, G. V., E. B. Sherr and B. S. Sherr. 1994. Release and consumption of DMSP from Emiliania huxleyi during grazing by Oxyrrhis marina. Mar. Ecol. Prog. Ser. $/ 1 /$ : $111-119$.

44. Zimmermann. R., R. Iturriaga and J. Becker-Birck. 1978. Simulataneous determination of the total number of aquatic bacteria and the number thereof involved in respiration. Appl. Environ. Microbiol. 36: 925-935.

45. Zweifel, U. L. and C. Hagstrem. 1995. Total counts of marine bacteria include a large fraction of non-nucleoid-containing bacteria (ghosts). Appl. Environ. Microbiol. 61: 2180-2185. 


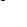

